\title{
PENGARUH KEJADIAN WASTE DENGAN PENDEKATAN LEAN HOSPITAL TERHADAP PROFITABILITAS INSTALASI FARMASI MELALUI PENGENDALIAN PRODUKSI DI ERA BPJS
}

\author{
Yany Khoirurakhmawati,Nikma Fitriasari, Fiella Rahmatika, Dya \\ Luciana,Iqbal S \\ Universitas Brawijaya Malang, Jl. Veteran Malang, 65145, Indonesia \\ e-mail : yanynadhir@gmail.com
}

\section{Abstract}

Background: Change in claim payment of Healthcare and Social Security Agency (BPJS) requires hospitals to improve the management using lean hospital approach. Hospital pharmacy installation attempts to reduce waste and control production costs to increase profitability. Objective: The study aimed to know the effect of waste events with lean hospital approach on the profitability of hospital pharmacy installation in XX Hospital through production costs control. Method: The study used quantitative observational research design with cross sectional study. The research was carried at XX Hospital in July-August 2018. The number of respondents was 36 obtained from total sampling technique.Then, Partial Least Square (PLS) was applied to analyze the obtained data. Results: The PLS results showed that waste had a direct negative effect on production costs control (0.727) while it had positive direct effect on profitability (3.757). Production costs control had positive direct effect on profitability (19.422). Waste did not significantly affect profitability through production costs control (-0.726). Conclusion: It can be concluded that waste decrease can increase production costs control. Effective and efficient production costs control can increase profitability. The more waste decrease results in the higher profitability.

Key word: waste, profitability, production cost, goverment hospital pharmacy instalation.

\section{Abstrak}

Latar Belakang: Perubahan pembayaran klaim Badan Kesehatan dan Jaminan Sosial (BPJS) mengharuskan rumah sakit meningkatkan manajemen menggunakan pendekatan lean hospital. Instalasi farmasi rumah sakit berupaya mengurangi waste dan mengendalikan biaya produksi untuk meningkatkan profitabilitas. Tujuan: Penelitian ini bertujuan untuk mengetahui pengaruh peristiwa waste dengan pendekatan lean hospital terhadap profitabilitas instalasi farmasi rumah sakit di RS XX melalui pengendalian biaya produksi. Metode: Penelitian ini menggunakan desain penelitian observasional kuantitatif dengan studi cross sectional. Penelitian ini dilakukan di Rumah Sakit XX pada Juli-Agustus 2018. Jumlah responden adalah 36 yang diperoleh dari teknik total sampling. Kemudian, Partial Least Square (PLS) diterapkan untuk menganalisis data yang diperoleh. Hasil: Hasil PLS menunjukkan bahwa waste memiliki efek negatif langsung pada kontrol biaya produksi $(0,727)$ sementara itu memiliki efek langsung positif pada profitabilitas $(3,757)$. Kontrol biaya produksi memiliki efek langsung positif pada profitabilitas $(19,422)$. Waste tidak secara signifikan mempengaruhi profitabilitas melalui kontrol biaya produksi (-0.726). Kesimpulan: Dapat disimpulkan bahwa penurunan waste dapat meningkatkan kontrol biaya produksi. Kontrol biaya produksi yang efektif dan efisien dapat meningkatkan profitabilitas. Semakin banyak penurunan waste menghasilkan profitabilitas yang lebih tinggi.

Kata kunci: waste, profitabilitas, biaya produksi, instalasi apotek rumah sakit pemerintah. 
Yany Khoirurakhmawati,Nikma Fitriasari, Fiella Rahmatika, Dya Luciana,Iqbal S: Pengaruh Kejadian Waste dengan Pendekatan Lean Hospital terhadap Profitabilitas Instalasi Farmasi melalui Pengendalian Produksi di Era BPJS

\section{PENDAHULUAN}

Era BPJS merupakan era rumah sakit melakukan lean manajemen karena sistem pembayaran klaim BPJS menggunakan INA-CBG. Pembayaran klaim dilakukan berdasarkan sistem pengelompokan jenis penyakit (Hakim, Nuswandari and Negoro, 2016). Pembayaran dengan sistem INA-CBG tidak diketahui secara detil berapa biaya obat setiap pasien, sehingga dibutuhkan strategi peningkatan mutu dan pembiayaan obat (Beard, Ashley and Chalkley, 2014). Obat di rumah sakit dikelola oleh unit farmasi.

Unit farmasi (IFRS, Instalasi Farmasi Rumah Sakit) merupakan unit revenue center. Unit farmasi melayani pengeloaan resep, pengambilan obat dari $80 \%$ pasien yang berobat. (Yusransyah, 2009). Peran penting unit farmasi adalah pengelolaan resep dan tanggung jawab terhadap keselamatan pasien dalam proses pengobatan pasien. (Siregar, 2004). Nilai penting IFRS juga ditunjukkan dalam perannya sebagai revenue center yang dapat memberikan kontribusi 50\% - 60\% dari total pendapatan total rumah sakit. Untuk itu, pelayanan IFRS memerlukan manajemen sistem yang baik terutama terkait produksi, waktu, sumber daya manusia agar tidak terjadi waste dan dapat memberikan pelayanan yang efektif dan berkualitas melalui pendekatan lean hospital (Kurniasih, Amalia and Anggraini, 2016).

Pendekatan lean adalah continous improvement dengan tujuan untuk menghilangkan waste dan kegiatan yang tidak bernilai tambah, dengan menargetkan langkah-langkah yang tidak menambah nilai kepada pelanggan, penundaan dan kesalahan untuk meningkatkan aliran proses (Maviglia, Saverio M; Yoo, Jane Y; Franz, Calvin; Featherstone, no date). Manajemen lean yang kuat dapat meminimalisir waste. Waste yang dapat ditemukan di rumah sakit adalah defects (kecacatan), over production (produksi berlebih), tranportation (angkutan), motion (pergerakan), waiting (waktu tunggu), inventory (persediaan), over procesing (proses 
Yany Khoirurakhmawati,Nikma Fitriasari, Fiella Rahmatika, Dya Luciana,Iqbal S: Pengaruh Kejadian Waste dengan Pendekatan Lean Hospital terhadap Profitabilitas Instalasi Farmasi melalui Pengendalian Produksi di Era BPJS

berlebih) dan human potential ( potensi sumberdaya manusia) (Graban, 2008).

Identifikasi Waste dan meminimalkan waste hasilnya adalah effisiensi biaya dan waktu (Hospital,et al, 2016). Biaya digunakan seeffisien mungkin termasuk biaya produksi. Penggunaan kas atau harta untuk suatu tujuan yang dibebankan saat ini atau yang akan datang adalah biaya. Biaya diartikan nilai pengorbanan untuk mendapatkan sesuatu yang bermanfaat melebihi satu periode akuntansi. Salah satu faktor yang mempengaruhi hasil produksi adalah biaya produksi, sehingga dibutuhkan perencanaan dan pengendalian yang baik. (Pratiwi, 2011).

Penentuan biaya produksi untuk menghitung profitabilitas. Profitabilitas adalah laba yang dihasilkan perusahaan dalam suatu periode. Keuntungan penjualan, modal saham dan aset merupakan profitabilitas. Laba yang dihasilkan dari seluruh modal yang dimiliki adalah gambaran profitabilitas. Rasio efektifitas manajemen adalah profitabilitas dibanding hasil penjualan dan investasi. Profit margin, basic earning power, return on assets dan return on equity adalah faktor rasio profitabilitas (Sudarmadji and Sularto, 2007; Nurhayati, 2013).

Merujuk pada latar latar belakang di atas, penelitian ini bertujuan untuk melakukan analisa perngaruh waste dengan pendekatan lean hospital terhadap profitabilitas rumah sakit melalui pengendalian biaya produksi di IFRS X.

\section{KAJIAN PUSTAKA}

Lean merupakan suatu upaya terus menerus untuk menghilangkan pemborosan atau waste dan meningkatkan nilai tambah (value added) produk barang maupun jasa agar memberikan nilai kepada pelanggan atau customer value. Tujuan lean ialah untuk meningkatkan customer value melalui peningkatan terus menerus rasio antara nilai tambah terhadap 
Yany Khoirurakhmawati,Nikma Fitriasari, Fiella Rahmatika, Dya Luciana,Iqbal S: Pengaruh Kejadian Waste dengan Pendekatan Lean Hospital terhadap Profitabilitas Instalasi Farmasi melalui Pengendalian Produksi di Era BPJS

waste (the value-to-waste ratio) (Adellia, Setyanto, Farela, \& Tantrika, 2014).

Lean di rumah sakit memiliki tantangan tersendiri. Manajer kesehatan menggunakan praktik lean untuk mengurangi biaya, meningkatkan kualitas dan keamanan pasien, menghindari pemborosan dan memperkaya pekerjaan. Prinsip-prinsip lean yang mengurangi waste meliputi: menentukan nilai pelanggan, mengidentifikasi aliran nilai, menciptakan proses aliran, menyoroti permintaan dan memprioritaskan penyelesaian masalah (Hwang, Hwang, \& Hong, 2014)

Waste merupakan sebuah kegiatan yang menyerap atau memboroskan sumber daya seperti pengeluaran biaya ataupun waktu tambahan tetapi tidak menambahkan nilai apapun dalam kegiatan tersebut. Prinsip lean dan alat pengukurnya adalah: 1. Mengurangi waste dengan value stream mapping, pemecahan masalah, Genchi Gembutsu ( menuju dimana pekerjaan terselesaikan ) dan 5 Why's, 2. Menjalankan pull system, quick changeover, one-piece dan continuous flow, Kanban, heijunka (leveled production), takt time planning, 3. Menerapkan Jidoka (buat masalah tampak) dengan cara visual tool, 5S, poka yoke (error profing), andon ( beri perhatian khusus dan pelajari masalah), 4.Single market Quality dengan cara stabilisasi dan proses terstandar, 5. Continous improvement dengan cara Kaizen dan disiplin, 6.Respect for people dengan cara keselamatan kerja, kerja tim, pendidikan dan pelatihan dan penghargaan (Lambert, 2008). Waste yang dapat di temukan di rumah sakit menurut Graban 2008 adalah defects (kecacatan), over production ( produksi berlebih), tranportation (angkutan), motion (pergerakan), waiting (waktu tunggu), inventory (persediaan), over procesing (proses berlebih) dan human potential ( potensi sumberdaya manusia) (Lambert, 2008).

Metode identifikasi waste adalah dengan menggunakan waste assessment model (WAM) yang terdiri dari seven waste relationship (SWR), waste relationship matrix (WRM) dan waste assessment questionnaire (WAQ) serta value stream maping (VSM) (Prayogo \& Octavia, 2013; Utama, Dewi, 
Yany Khoirurakhmawati,Nikma Fitriasari, Fiella Rahmatika, Dya Luciana,Iqbal S: Pengaruh Kejadian Waste dengan Pendekatan Lean Hospital terhadap Profitabilitas Instalasi Farmasi melalui Pengendalian Produksi di Era BPJS

\& Mawarti, 2016). Waste Assessment Model merupakan suatu model untuk pencarian permasalahan waste dan mengidentifikasi untuk mengeliminasi waste. Model ini menggambarkan hubungan antar seven waste $(O$ : Overproduction, P: Processing, I: Inventory, T: Transportation, D: Defects, W: Waiting, dan M: Motion). Dalam konsep Seven Waste Relationship, semua jenis waste bersifat interdependent dan berpengaruh terhadap jenis lain. Waste Relationship Matrix (WRM) merupakan matriks yang digunakan untuk menganalisis kriteria pengukuran. Waste Assessment Questionnaire (WAQ) dibuat untuk mengidentifikasi dan mengalokasikan waste yang terjadi pada lini produksi (Hidayat \& Nurlina, 2000; Shodiq \& Khannan, 2015). Waste Assesment Question bisa juga menggunakan seven waste relationship dengan kriteria pertanyaan tujuh jenis waste.

Pengendalian biaya produksi adalah pengendalian biaya bahan baku, tenaga kerja langsung dan overhead (Rosidah dan Krisnadi, 2008). Pengendalian bahan baku adalah penggunaan yang effisien bahan baku dengan kualitas dan kuantitas yang bagus. Pengendalian bahan baku dilakukan dari mulai perencanaan pembelian, penerimaan, persediaan, penggunaan dan bahan sisa (Hapsari et all,2013). Pengendalian biaya tenaga kerja langsung adalah mengendalikan biaya tenaga kerja yang terlibat dalam proses produksi. Tenaga kerja diperhitungkan efisiensi dalam melakukan pekerjaan sesuai pendistribusian keahlian dan proses produksi sehingga analisis selisih tenaga dapat dikendalikan. Pengendalian jam dan biaya lembur tenaga kerja dan biaya kontrak tenaga kerja termasuk dalam pengendalian biaya tenaga kerja langsung. Pengendalian biaya overhead adalah pengendalian biaya-biaya produksi selain bahan langsung dan tenaga kerja langsung. Biaya-biaya tersebut disebut juga biaya produksi tak langsung (Hapsari,2013)

Profitabilitas merupakan kemampuan suatu perusahaan untuk mendapatkan laba dalam suatu periode tertentu. Profitabilitas badan usaha menghasilkan laba dengan menggunakan seluruh modal yang 
Yany Khoirurakhmawati,Nikma Fitriasari, Fiella Rahmatika, Dya Luciana,Iqbal S: Pengaruh Kejadian Waste dengan Pendekatan Lean Hospital terhadap Profitabilitas Instalasi Farmasi melalui Pengendalian Produksi di Era BPJS

dimiliki. Profitabilitas yaitu rasio dari penjualan dan investasi. Rasio profitabilitas terdiri atas profit margin, basic earning power, return on assets, dan return on equity (Nurhayati, 2013; Sudarmadji \& Sularto, 2007). Profit margin adalah kemampuan badan usaha menghasilkan keuntungan dibandingkan dengan penjualan. Basic earning ower adalah kemampuan perusahaan mengasilkan keuntungan per lembar saham. Return of asset adalah keuntungan digunakan untuk mengembalikan aset. Return on equity adalah kemampuan perusahaan menghasilkan laba berdasarkan modal tertentu (Tandiotong et all, 2010).

Pelayanan farmasi rumah sakit merupakan salah satu kegiatan di rumah sakit yang menunjang pelayanan kesehatan yang bermutu (Permenkes No 1197 tahun 2004 tentang pelayanan farmasi). Pelayanan farmasi rumah sakit adalah bagian yang tidak terpisahkan dari sistem pelayanan kesehatan rumah sakit yang beorientasi kepada pelayanan pasien (Permenkes no 1333 tahun 1999 tentang standar pelayanan rumah sakit). Instalasi Farmasi rumah sakit adalah suatu bagian/ unit/ divisi atau fasilitas di rumah sakit, tempat penyelenggaraan semua kegiatan pekerjaan kefarmasian yang ditujukan untuk keperluan rumah sakit itu sendiri (Siregar dan Amalia, 2004). Pelayanan farmasi terdiri dari pelayanan paripurna yang mencakup perencanaan, pengadaan, produksi, penyimpanan perbekalan kesehatan/sediaan farmasi. Perbekalan kesehatan/ sediaan farmasi terdiri dari dispensing obat berdasarkan resep bagi penderita saat tinggal dan rawat jalan, pengendalian mutu dan pengendalian distribusi, penggunaan seluruh perbekalan kesehatan di rumah sakit. Pelayanan farmasi klinik umum dan spesialis mencakup pelayanan langsung pada penderita dan pelayanan klinik yang merupakan program rumah sakit secara keseluruhan (Siregar dan Amalia, 2004). 
Yany Khoirurakhmawati,Nikma Fitriasari, Fiella Rahmatika, Dya Luciana,Iqbal S: Pengaruh Kejadian Waste dengan Pendekatan Lean Hospital terhadap Profitabilitas Instalasi Farmasi melalui Pengendalian Produksi di Era BPJS

\section{HIPOTESIS}

Waste merupakan sebuah kegiatan yang memboroskan sumber daya dan tidak menambahkan nilai pada kegiatan (Lambert,2008). Sumberdaya merupakan komponen dari biaya produksi (Rosidah dan Krisnadi,2008). Selain sumberdaya, biaya produksi adalah biaya overhead dan biaya bahan baku. Hipotesa pertama, waste berpengaruh signifikan terhadap pengendalian biaya produksi di instalasi farmasi rumah sakit $X$.

Pengendalian biaya produksi adalah pengendalian biaya bahan baku, biaya tenaga kerja dan biaya overhead (Rosidah dan Krisnadi,2008). Biaya produksi dapat dikendalikan maka profitabilitas meningkat (Hapsari et al, 2013). Hipotesa kedua, pengendalian biaya produksi berpengaruh terhadap peningkatan profitabilitas di instalasi farmasi rumah sakit $X$.

Kegiatan pemborosan sumberdaya dapat meningkatkan biaya produksi. Efisiensi biaya produksi daapat meningkatkan laba, karena dapat mengurangi jumlah pengeluaran perusahaan tanpa adanya kenaikan harga dan pengurangan kualitas (Hidayat and Salim, 2013). Hipotesa ketiga, waste berpengaruh terhadap peningkatan profitabilitas melalui pengendalian biaya produksi di instalasi farmasi rumah sakit $\mathrm{X}$.

\section{METODE}

Penelitian ini bersifat kuantitatif observasional dengan cross sectional di sebuah rumah sakit umum $X$ tipe $C$ milik pemerintah daerah. Pengambilan data dilakukan dengan teknik total sampling pada petugas instalasi farmasi. Instrumen penelitian berupa kuesioner tertutup dengan skala Likert yang dibagikan untuk dilengkapi secara mandiri oleh responden pada bulan Juli sampai Agustus 2018. Variabel yang digunakan adalah waste sebagai variabel bebas, pengendalian biaya produksi dan profitabilitas sebagai variabel tergantung. Pengolahan data dilakukan dengan cara Partial Least Square (PLS). 
Yany Khoirurakhmawati,Nikma Fitriasari, Fiella Rahmatika, Dya Luciana,Iqbal S: Pengaruh Kejadian Waste dengan Pendekatan Lean Hospital terhadap Profitabilitas Instalasi Farmasi melalui Pengendalian Produksi di Era BPJS

\section{HASIL DAN PEMBAHASAN}

Responden yang terlibat dalam penelitian ini berjumlah 36 pegawai instalasi farmasi rumah sakit XX. Karakteristik responden mayoritas berusia kurang dari 25 tahun sebesar 25,9\%, jenis kelamin wanita sebesar $70,4 \%$, status pegawai tidak tetap sebesar 77,8\%, status belum kawin sebesar 48,1\%, pendidikan SLTA/Sederajat sebesar 37\%, staf instalasi farmasi sebesar 88,9\%, dengan lama bekerja 1-5 tahun sebesar 59,3\%. Karakteristik responden cukup homogen karena diambil dari satu unit pelayanan yang memiliki standar rekrutmen dan profesi yang jelas. Kemampuan responden dalam memahami pernyataan yang diajukan dalam instrumen penelitian didukung dengan kedewasaan umur, telah bekerja lebih dari satu tahun, memiliki pengalaman kerja dan berpendidikan

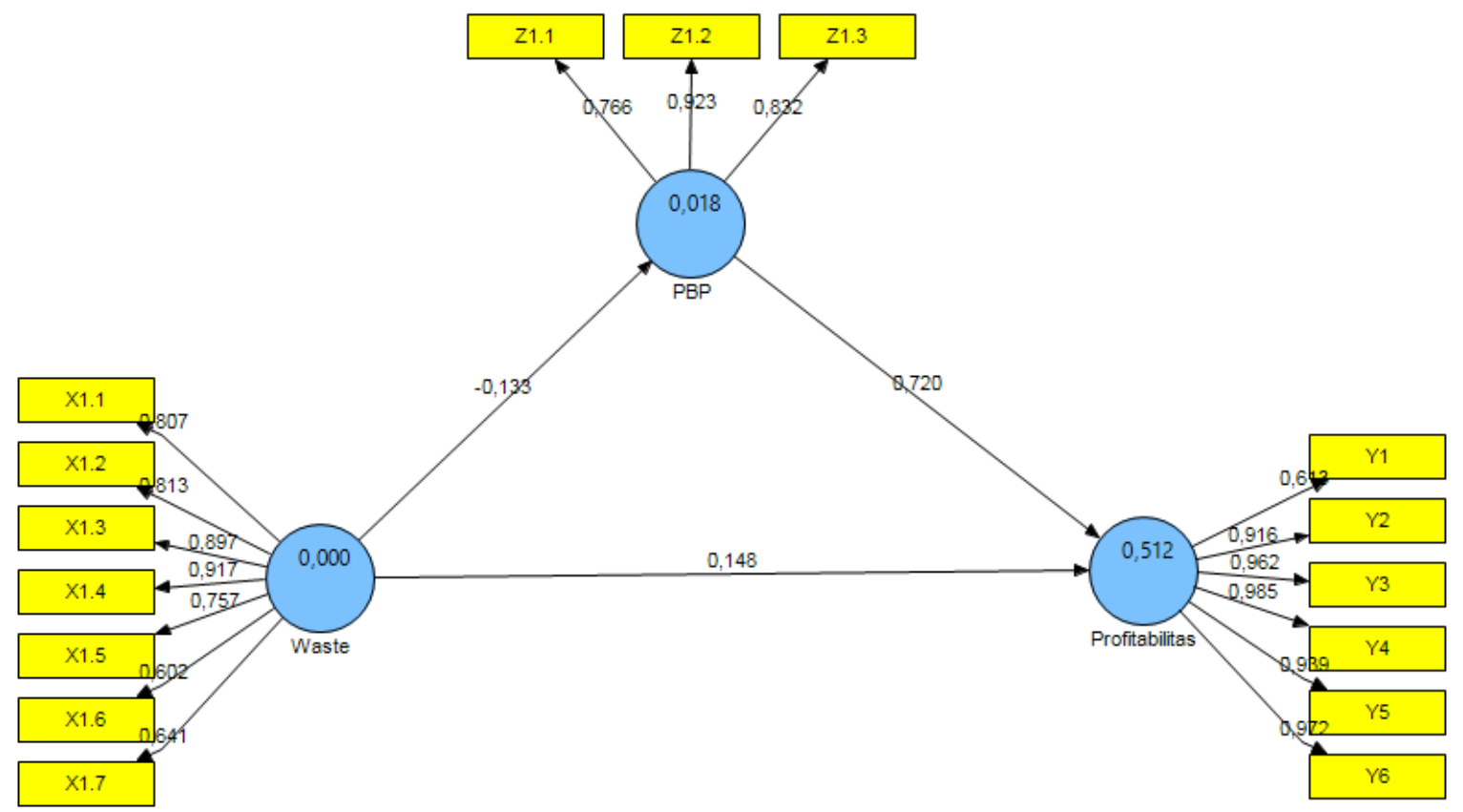

Gambar 1. Diagram PLS Penelitian

Hasil analisis PLS didapatkan nilai loading factor, nilai godness of fit dan nilai signifikasi tiap variabel, sesuai Gambar 1. 
Yany Khoirurakhmawati,Nikma Fitriasari, Fiella Rahmatika, Dya Luciana,Iqbal S: Pengaruh Kejadian Waste dengan Pendekatan Lean Hospital terhadap Profitabilitas Instalasi Farmasi melalui Pengendalian Produksi di Era BPJS

Model pengukuran variabel waste juga menginformasikan bahwa indikator inappropriate processing (X1.4) memiliki nilai loading paling besar 0,917. Model pengukuran variabel pengendalian biaya produksi juga menginformasikan bahwa indikator pengendalian biaya SDM (Z1.2) paling besar 0,985. Model pengukuran variabel profitabilitas juga menginformasikan bahwa indikator kinerja rumah sakit (Y4) memiliki nilai loading paling besar 0,985 .

Hasil goodness and fit sebagai relevansi teori menunjukkan bahwa keragaman profitabilitas sebesar 52,0\% seperti dijelaskan oleh model, atau kontribusi waste serta pengendalian biaya produksi pengaruh pada profitabilitas secara keseluruhan baik langsung maupun tidak sebesar $52.0 \% .48 \%$ kontribusi faktor lain tidak dibahas dalam penelitian ini.

Nilai T-statistik $\geq$ T-tabel $(1,96)$ dinyatakan berpengaruh signifikan variabel eksogen terhadap variabel endogen, merupakan kriteria. Waste perpengaruh negatif terhadap pengendalian biaya produksi $(0,727)$. Waste berpengaruh positif terhadap probabilitas $(3,757)$. Pengendalian biaya produksi berpengaruh positif terhadap profitabilitas (19.422). akan tetapi tidak terdapat pengaruh signifikan waste terhadap profitabilitas melalui pengendalian biaya produksi . Pengendalian biaya produksi memiliki total efek yang besar pada profitabilitas.

Nilai loading factor sebagai kontribusi variabel pada inapropriated processing sebesar 0,917 merupakan faktor yang lebih besar dari faktor dalam kriteria waste, sesuai dengan penelitian (Indrawati and Ridwansyah, 2015), yang menyatakan waste dominan ditemukan pada industri adalah inappropriate processing, product defect dan waiting. (Hazmi, Karningsih and Supriyanto, 2012). Inappropriate processing dapat menambah waktu produksi sehingga mengakibatkan keterlambatan produksi (Ristyowati, Muhsin and Nurani, 2017). Nilai loading factor, dimensi pengendalian biaya SDM (Y1.2) sebesar 0,985 merupakan loading factor terbesar pada pengendalian biaya produksi. Beberapa penelitian 
Yany Khoirurakhmawati,Nikma Fitriasari, Fiella Rahmatika, Dya Luciana,Iqbal S: Pengaruh Kejadian Waste dengan Pendekatan Lean Hospital terhadap Profitabilitas Instalasi Farmasi melalui Pengendalian Produksi di Era BPJS

perhitungan sumber daya manusia sebagai tenaga kerja $37 \%$ dari keseluruhan pembiayaan produksi (Anik, 2013; Malue, 2013; Ardhian et al., 2016). Indikator kinerja rumah sakit (Y4) memiliki nilai loading paling besar 0,985, merupakan indikator dominan dari profitabilitas rumah sakit, sesuai dengan penelitian (Asmini and Fitriyani, 2018). Perubahan dalam bentuk pelayanan rumah sakit dapat mempengaruhi efisiensi dan efektifitas (Niaga, 2013). Aktivitas pelayanan rumah sakit yang tergambar pada kinerja rumah sakit berpengaruh dengan profitabilitas rumah sakit (Sugiono and Wahono, 2016).

Hasil goodness and fit adalah 52,0\%, artinya keragaman profitabilitas sebesar 52,0\%. Kontribusi waste serta pengendalian biaya produksi berpengaruh pada profitabilitas secara langsung maupun tidak sebesar $52.0 \%$. Faktor lain yang tidak dibahas pada penelitian ini sebesar $48.0 \%$ misalnya tarif (Kaunang and Walandouw, 2015), kepemilikan (Gede and Astini, 2012), jumlah pasien (Rovi, 2019) merupakan beberapa faktor mempengaruhi profitabilitas.

Kriteria pengujian hipotesis pengaruh langsung menyatakan bahwa Waste perpengaruh negatif terhadap pengendalian biaya produksi $(0,727)$. Waste menurut rumah sakit XX berpengaruh negatif, pengendalian bahan baku, pengendalian biaya SDM dan pengendalian biaya overhead. Rumah sakit XX merupakan rumah sakit pemerintah, instalasi farmasi rumah sakit merupakan instalasi fungsional yang bekerja sebagai profesional farmasi, pengadaan barang dan rencana tenaga kerja tidak dilakukan dalam unit tersebut.(Kemenkes RI, 2017).

Kriteria pengujian hipotesis pengaruh langsung menyatakan waste berpengaruh signifikan terhadap profitabilitas $(1,96)$. Pengurangan waste dalam proses produksi dapat meningkatkan value added sehingga meningkatkan profitabilitas (Beard, Ashley and Chalkley, 2014; Ristyowati, Muhsin and Nurani, 2017). Kriteria pengujian pengaruh langsung pengendalian biaya produksi terhadap profitabilitas adalah 
Yany Khoirurakhmawati,Nikma Fitriasari, Fiella Rahmatika, Dya Luciana,Iqbal S: Pengaruh Kejadian Waste dengan Pendekatan Lean Hospital terhadap Profitabilitas Instalasi Farmasi melalui Pengendalian Produksi di Era BPJS

19.422 dapat diartikan berpengaruh signifikan. Hasil ini sesuai dengan penelitian (Aliu, 2013; Saputra, 2014) bahwa efisiensi pengendalian biaya produksi dapat meningkatkan profitabilitas.

Pengaruh waste terhadap profitabilitas melalui pengendalian biaya produksi, nilai $\mathrm{T}$ statistics -0.726 , nilai $\mathrm{T}$ statistics $<\mathrm{T}$ tabel (1.96). Waste tidak berengaruh terhadap profitabilitas melalui pengendalian biaya produksi. Sebagian pengendalian biaya produksi pada rumah sakit pemerintah tergantung anggaran pemerintah. Anggaran pemerintah tergantung pada faktor internal dan eksternal rumah sakit (Gumolili, 2012).

Pengendalian biaya produksi memiliki total efek terbesar terhadap profitabilitas yaitu 0.720 . Faktor utama yang berpengaruh pada profitabilitas adalah pengendalian biaya produksi. Profitabilitas didapat dengan mengurangi biaya realitas produksi dengan biaya anggaran produksi, bila biaya realitas lebih rendah maka menguntungkan, tapi bila lebih besar maka merugikan (Horngren, Datar and Rajan, 2000). Efisiensi biaya produksi daapat meningkatkan laba, karena dapat mengurangi jumlah pengeluaran perusahaan tanpa adanya kenaikan harga dan pengurangan kualitas (Hidayat and Salim, 2013).

\section{KESIMPULAN}

Penurunan waste dapat meningkatkan pengendalian biaya produksi. Pengendalian biaya produksi yang efektif dan efisien dapat meningkatkan profitabilitas. Waste semakin turun semakin tinggi profitabilitas.

\section{SARAN}

Faktor keragaman profitabilitas mampu dijelaskan oleh model secara keseluruhan sebesar 52.0\%, masih ada $48 \%$ faktor yang tidak mampu dijelaskan dalam penelitian ini. Penelitian selanjutnya diharapkan dapat meneliti faktor lain dari profitabilitas di instalasi farmasi rumah sakit pemerintah. 
Yany Khoirurakhmawati,Nikma Fitriasari, Fiella Rahmatika, Dya Luciana,Iqbal S: Pengaruh Kejadian Waste dengan Pendekatan Lean Hospital terhadap Profitabilitas Instalasi Farmasi melalui Pengendalian Produksi di Era BPJS

\section{DAFTAR PUSTAKA}

Aliu, S. (2013) 'Penerapan Akuntansi Pertanggungjawaban Sebagai Alat Pengendalian Biaya Produksi Dan Penilaian Kinerja', 1(3), pp. 160-168.

Anik, A. P. (2013) 'Evaluasi Penerapan Akuntansi Pertanggungjawaban sebagai Alat Pengendalian Biaya Produksi', Emba, 1(4), pp. 1667-1676.

Ardhian, S. et al. (2016) 'Alat Pengendalian Biaya Produksi Dan Penilaian Kinerja Pada Prima Donut ' S Kediri.'

Asmini and Fitriyani, I. (2018) 'Efektifitas, Efisiensi dan Kontribusi Retribusi Pelayanan Kesehatan pada Puskesmas Kecamatan Rhee terhadap Retribusi Kesehatan Kabupaten Sumbawa Tahun 2011-2016', Jurnal Ekonomi dan Bisnis, 15(1), pp. 99-110.

Beard, J., Ashley, M. and Chalkley, D. (2014) 'Improving The Efficiency Of A Hospital Pharmacy Service: The Journey Of One Hospital Pharmacy', pp. 208-215. doi: 10.1136/ejhpharm-2013-000429.

Gede, L. and Astini, S. (2012) 'Kepemilikan Terhadap Struktur Modal Dan Kinerja Perusahaan Farmasi Yang Terdaftar Di Bursa Efek Indonesia ( BEI ) Fakultas Ekonomi dan Bisnis Universitas Udayana, Bali , Indonesia perusahaan memperoleh laba . Rasio profitabilitas diukur dengan dua pendek', pp. 3309-3321.

Graban, M. (2008) Lean Hospital: Improving Quality, Patient Safety, And Employee Satisfaction.

Gumolili, S. A., Dinas, S. and Pemprov, E. (2012) 'Analisa Faktor-Faktor Penyebab Change Order Dan Pengaruhnya Terhadap Kinerja Waktu Pelaksanaan Provinsi Sulawesi Utara', 2(4).

Hakim, M. S., Nuswandari, A. I. and Negoro, N. P. (2016) 'Perbandingan profatibilitas pasien BPJS dan pasien umum di Rumah sakit Brawijaya Surabaya dengan pedekatan Costumer Profitability Analysis', Jurnal Sosial Humaniora, 9(2), pp. 197-206. doi: 10.12962/j24433527.v9i2.1652.

Hazmi, F. W., Karningsih, P. D. and Supriyanto, H. (2012) 'Penerapan Lean Manufacturing Untuk Mereduksi waste di PT ARISU', Jurnal Teknik Its, 1(1), p. F-135 - 140.

Hidayat, L. and Salim, S. (2013) 'Analisis Biaya Produksi Dalam Meningkatkan Profitabilitas Perusahaan', (April 2013).

Horngren, C. T., Datar, S. M. and Rajan, M. (2000) Cost Accounting. 
Yany Khoirurakhmawati,Nikma Fitriasari, Fiella Rahmatika, Dya Luciana,Iqbal S: Pengaruh Kejadian Waste dengan Pendekatan Lean Hospital terhadap Profitabilitas Instalasi Farmasi melalui Pengendalian Produksi di Era BPJS

Indrawati, S. and Ridwansyah, M. (2015) 'Manufacturing Continuous Improvement Using Lean Six Sigma: An Iron Ores Industry Case Application', Procedia Manufacturing. Elsevier B.V., 4(Iess), pp. 528-534. doi: 10.1016/j.promfg.2015.11.072.

Kaunang, B. and Walandouw, S. K. (2015) 'Penerapan Metode Activity Based Costing System Dalam Menentukan Besarnya Tarif Jasa Rawat Inap Pada Rumah Sakit Umum Bethesda', Emba, 3(1), pp. 1214-1221.

Kemenkes RI (2017) 'Peraturan Menteri Kesehatan Republik Indonesia Nomor 72 tahun 2016 tentang Standar Pelayanan Kefarmasian di Rumah Sakit.'

Kurniasih, F. D., Amalia, L. and Anggraini, Y. (2016) 'Analisis Mutu Pelayanan Farmasi Di Unit Rawat Jalan Rumah Sakit X Di Bogor', 1(1), pp. 89-106.

Malue, J. (2013) 'Analisis penerapan target costing sebagai sistem pengendalian biaya produksi pada PT.Celebes Mina Pratama', Emba, 1(3), pp. 949-957.

Maviglia, Saverio M; Yoo, Jane Y; Franz, Calvin; Featherstone, E. et al (no date) 'Cost-Benefit Analysis of a Hospital Pharmacy Bar Code Solution', . Archives of Internal Medicine, Vol. 167, (): 788-94.).

Niaga, D. A. N. C. (2013) 'Perbandingan sistem bagi hasil dan bunga di bank muamalat indonesia dan cimb niaga', 6(3). doi: 10.15294/jejak.v7i1.3596.

Nurhayati, M. (2013) 'Profitabilitas, likuiditas dan ukuran perusahaan pengaruhnya terhadap kebijkan dividen dan nilai perusahaan sektor non jasa', Jurnal Keuangan dan Bisnis, 5(2), pp. 144-153.

Pratiwi, J. (2011) 'Penerapan Biaya Standar Dalam Pengendalian Biaya Produksi Pada Pt. Pertani (Persero) Cabang Sulawesi Utara', 1(4), pp. 1617-1626.

Ristyowati, T., Muhsin, A. and Nurani, P. P. (2017) 'Minimasi Waste Pada Aktivitas Proses Produksi Dengan Konsep Lean Manufacturing ( Studi Kasus di PT . Sport Glove Indonesia )', Jurnal Optimasi Sistem Industri, 10(1), pp. 85-96.

Rovi, L. (2019) 'Analisis komparasi efisiensi operasional Instalasi Rawat Jalan ( IRJA ) terhadap kinerja profitabilitas dengan metode data envelopment analysis ( DEA ): Studi pada RSUD Kertosono dan RSUD Nganjuk', (Chapter 3), pp. 1-5.

Saputra, B. (2014) 'Evaluasi efektivitas pengendalian biaya produksi dan efisiensi biaya produksi', (May 2013).

Siregar, C. J. P. (2004) Farmasi Rumah Sakit Teori dan Terapan. Jakarta: EGC. 
Yany Khoirurakhmawati,Nikma Fitriasari, Fiella Rahmatika, Dya Luciana,Iqbal S: Pengaruh Kejadian Waste dengan Pendekatan Lean Hospital terhadap Profitabilitas Instalasi Farmasi melalui Pengendalian Produksi di Era BPJS

Sudarmadji, A. M. and Sularto, L. (2007) 'Pengaruh Ukuran Perusahaan, Profitabilitas, Leverage, dan Tipe Kepemilikan Perusahaan Terhadap Luas Voluntary Disclosure Laporan Keuangan Tahunan', Proceeding PESAT(Psikologi, Ekonomi, Sastra, Arsitek \& Sipil), 2, pp. 53-61.

Sugiono and Wahono, B. (2016) 'Analisis Kinerja Keuangan Badan Layanan Umum Daerah RSUD dr. Saiful Anwar Malang', Jurnal Manajemen, (106), pp. 97-109.

Yusransyah (2009) 'Analisis pengelolaan obat di instalasi farmasi rumah sakit umum pku muhammadiyah bantul tahun 2006 - 2008 disertai diskusi kelompok kecil', EDC Gajah mada University, pp. 2008-2010. 